\title{
A 500-year history of forest fires in Sala area, central Sweden, shows the earliest known onset of fire suppression in Scandinavia
}

\author{
Guilherme Alexandre Stecher Justiniano Pinto ${ }^{1}$ • Mats Niklasson ${ }^{1,2} \cdot$ Nina Ryzhkova ${ }^{3,4} \cdot$ Igor Drobyshev $^{1,3,4}$
}

Received: 26 August 2020 / Accepted: 23 October 2020 / Published online: 13 November 2020

(C) The Author(s) 2020

\begin{abstract}
The Sala fire in the Västmanland County of central Sweden that burned about 14,000 ha in 2014 has been the largest fire recorded in the modern history of Sweden. To understand the long-term fire history of this area, we dendrochronologically dated fire scars on Scots pine (Pinus sylvestris L.) trees (live and deadwood) to reconstruct the fire cycle and fire occurrence in the area affected by the 2014 fire. We identified 64 fire years, using a total of 378 pine samples. The earliest reconstructed fire dated back to 1113 AD. The spatial reconstruction extended over the period of 1480-2018 AD. Lower levels of fire activity (fire cycle, FC $=43$ years, with the central $90 \%$ of the distribution limited by 35 to 57 years) dominated in the earlier period (1480-1690 AD) that was followed by a strong decrease in fire activity since 1700 ( $\mathrm{FC}=403$ years, with $90 \%$ of the distribution being within 149 to 7308 years), with a fire-free period between 1756 and 2014. Sala area, therefore, features the earliest known onset of fire suppression in Scandinavia. The high demand for timber during the peak in mining activities in the study area around the 1700-1800s, accompanied by passive fire suppression policies, were possibly the main drivers of the decline in fire activity. Superposed epoch analysis (SEA) did not show significant departures in the drought proxy during the ten years with the largest area burned between 1480 and1690. It is unclear whether the result is due to the relatively small area sampled or an indication that human controls of fires dominated during that period. However, significant departures during the following period with low fire activity (1700-1756), which just preceded the last fire-free period, suggested that the climate became an increasingly important driver of fire during the onset of the suppression period. We speculate that the lack of major firebreaks, the homogenization of forests, and the lack of burned areas with low fuel loads might contribute to the occurrence of the exceptionally large 2014 fire in Sala.
\end{abstract}

Keywords Forest fire cycle $\cdot$ Regime shift $\cdot$ Superposed epoch analysis $\cdot$ Disturbance histories $\cdot$ Land use practices

\section{Introduction}

Forest fires are the main drivers of boreal ecosystem dynamics (Johnson 1992; Johnstone and Chapin 2006) and forest carbon emissions (Conard and Ivanova 1997; Amiro et al. 2001). In the boreal zone, forest fires are mostly driven by regional climate

Communicated by Wolfgang Cramer

Igor Drobyshev

igor.drobyshev@slu.se

Guilherme Alexandre Stecher Justiniano Pinto

guilherme.pinto@slu.se

Mats Niklasson

mats.niklasson@nordensark.se

Nina Ryzhkova

ryzhkova@krc.karelia.ru conditions with landscape properties, primarily vegetation and topography, affecting their frequency, spread, and severity (Hellberg et al. 2004; Pinto et al. 2020). Under natural conditions, forest fires are ignited by lightning. In many parts of the boreal zone, humans have been providing additional, and often dominating, sources of ignition (Granström 1993; Achard et al. 2008).

1 Southern Swedish Forest Research Centre, Swedish University of Agricultural Sciences, PO Box 49, SE-230 53 Alnarp, Sweden

2 Foundation Nordens Ark, Åby säteri, SE-456 93 Hunnebostrand, Sweden

3 Institut de recherche sur les forêts, Université du Québec en Abitibi-Témiscamingue, 445 Boulevard de l'université, Rouyn-Noranda J9X 5E4, Canada

4 Forest Research Institute of the Karelian Research Centre of the Russian Academy of Sciences, 11 Pushkinskaya St, Petrozavodsk, Republic of Karelia, Russian Federation 185910 
In Scandinavia, the fire regime varied significantly during recent centuries. Landscape-scale fire-scar-based reconstructions in Sweden and Norway have shown a pattern with few, large climate-driven fires dominating the fire regime up to the early $1600 \mathrm{~s}$ and small but more frequent fires during most of the $1600 \mathrm{~s}$ and 1700s (Niklasson and Granstrom 2000; Niklasson et al. 2010). A strong decline in fire activity from the 1800 s and onwards (Niklasson and Granstrom 2000; Rolstad et al. 2017) was due to the introduction of fire suppression policies to support a growing timber industry (Högbom 1934; Niklasson and Granstrom 2000; Drobyshev et al. 2012). Climate variability might have played a role in the decline of fire activity since the 1800s (Drobyshev et al. 2016). Today, between 3000 and 4000 fires are recorded in the Swedish forests annually, with the total area burned being around $0.008 \%$ of the forested area per year, corresponding to the fire cycle of around $10^{4}$ years (Drobyshev et al. 2012; MSB 2017). In comparison, the fire cycle in the Northern European boreal forests prior to the 1700 s varied between 50 and 300 years (Niklasson and Granstrom 2000; Drobyshev et al. 2012; Ryzhkova et al. 2020).

The effectiveness of fire suppression in the modern Swedish forests makes large fires rare events. However, an exceptionally large fire in the proximity of Sala town in Västmanland County, central Sweden, burned $\sim 14,000$ ha during August 2014 (MSB 2015). The Sala fire is likely the largest fire on record in modern Sweden, a magnitude larger than other known modern large fires (Högbom 1934; Föreningen Skogen 2019).

A strong public interest in understanding the disturbance history in Sala provided the initial impetus to develop this reconstruction. In particular, despite a large amount of existing fire history reconstruction in Scandinavia (Drobyshev et al. 2014), the vast majority of them do not represent the history of mesic and, currently, heavily managed forests. The available reconstructions have been commonly developed in either protected forests, managed with low intensity or more xeric sites (Drobyshev et al. 2014). The primary reasons for this bias are the increasingly difficult sample collection in forests subject to "regular" management (so-called production forests) and the interest of the research teams in maximizing the chronology time span by sampling on the drier sites where preservation of the deadwood is better than in the mesic forests. Mesic production forests have, therefore, been largely neglected by dendrochronological studies, although they represent $94 \%$ of the total forest area in Sweden (Statistics Sweden 2018).

An incentive for conducting this study was the consideration that obtaining a long-term fire record from an area subject to century-long intensive forest exploitation would make such a reconstruction an important addition to the existing network of sites with developed long-term fire histories. Indeed, the region around the Sala municipality has been under the influence of forest management since the establishment of mining communities in the 1300s (Emanuelsson and Segerstrom 2002), and the forest use in the area is well-documented. The fact that mesic sites are poorly represented in the network of sites with currently available reconstructions further contributed to the rationale to undertake the reconstruction work.

We hypothesized that $(\mathrm{H} 1)$ the Sala area exhibited frequent fires prior to the onset of the fire suppression era, making its fire history broadly similar to other Northern European landscapes. We further hypothesized that (H2) the Sala area experienced a decline in fire activity earlier than the areas in other mid-boreal Swedish landscapes. We argued that as the Sala region has been an area of higher economic value for timber extraction and charcoal production for the mining industry, uncontrolled fire activity had the potential to cause tangible economic losses. The incentives to abandon fire as a high-risk agricultural tool and to suppress natural wildfires might have been, therefore, particularly strong in this region. The relative proximity of Sala to Stockholm (about $120 \mathrm{~km}$ ), the political and economic center of Sweden, might further facilitate enforcement of the fire-related policies. Last, we hypothesized that (H3) fire suppression resulted in a change in climate-fire interactions, making fires occurring in the suppression era spread during increasingly more fire-prone conditions, as compared to the pre-suppression period. We used a combination of dendrochronological reconstruction, fire-climate analysis, and comparison of our results with previously published reconstructions and data on the human population dynamics to address these hypotheses (Fig. 1). The results of the study contribute towards quantification of the historic disturbance regimes in mesic Scots pine (Pinus sylvestris L.) forests, the most common type of forest conditions in Sweden.

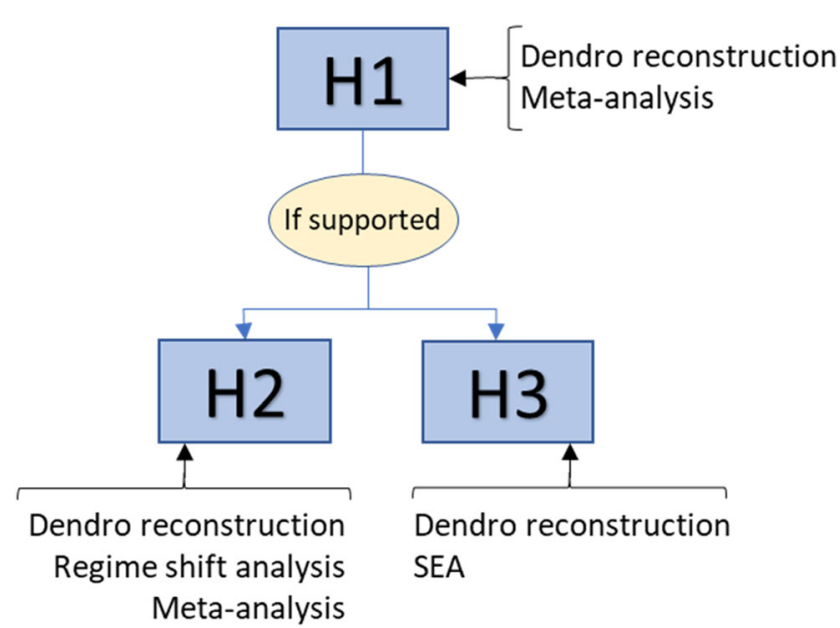

Fig. 1 Conceptual workflow of the study, linking the hypotheses with the specific data inputs. H1 through $\mathrm{H} 3$ are the study hypotheses (see Introduction section). "Dendro reconstruction" stands for dendrochronological reconstruction of fire history in Sala. Regime shift analysis is done on the dendrochronological reconstructed area burned and fire occurrence in the Sala area. Meta-analysis refers to the comparative analysis of previously published data on historical fire regimes and analysis of human dynamics in the area. SEA superposed epoch analysis 


\section{Material and methods}

\section{The study area}

The Sala municipality lies in central Sweden in Västmanland County, around 120 kilometers northwest of Stockholm. The climate of the area is mostly continental, with the long-term mean temperatures being $16{ }^{\circ} \mathrm{C}$ in July and $-4.1{ }^{\circ} \mathrm{C}$ in February (Wastenson et al. 1995). The annual mean precipitation ranges from 500 to $600 \mathrm{~mm}$ with snow depth reaching up to $50 \mathrm{~cm}$ in February. The growing season ranges between 170 and 180 days.

The soils are mostly till and peat with a bedrock consisting mostly of granite and granodiorite (Sjödin 2016). The study area lies predominantly within the southern boreal vegetation zone (Ahti et al. 1968; Wastenson et al. 1996). Västmanland County has a forested area of around 313000 ha (60\% of the county), from which around $96 \%$ are production forests, with Scots pine (Pinus sylvestris L.) forests as the most common forest type ( 28\%) (SLU 2017).

Numerous small fires dominate the contemporary fire regime of the region. Between 1998 and 2017, Västmanland County registered 1729 forest fires larger than $1 \mathrm{~m}^{2}$ (MSB 2017) with an average fire size of 7 ha and the median of 0.002 ha. Excluding the Sala fire, the average fire size is only 0.3 ha. Around $4.8 \%$ of the forest fires registered in this period were ignited by lightning; the rest were attributed to the human activity of different types. Within the area burned in 2014 , there is ca. $2.94 \mathrm{~km}^{2}(\sim 2.11 \%)$ of water bodies divided into small lakes with mires and bogs in the lower elevation areas. The elevation varies from 62 to 177 meters above sea level (Fig. 2).

\section{Field sampling and chronology development}

During the 2016-2018 period, we sampled the area burned in 2014 (Fig. 2) for dendrochronological reconstruction. The combined effects of the long history of mining, intense logging, and charcoal production have resulted in the extreme scarcity of old trees and snags. The 2014 fire itself consumed much of the deadwood. However, the openness created by salvage logging and the high mortality of canopy trees facilitated the visual spotting of older deadwood (mainly stumps from previous cuttings), which was our main source of information on the historical fire events. Although smoldering in the 2014 fire consumed a large number of older stumps, the surviving deadwood was visible and could be easily identified due to the total combustion of ground vegetation, duff, and humus layers, which normally cover old deadwood. Using the forest road network, we selected our sampling points, paying particular attention to rocky outcrops, xeric sites, and transition zones between dry and wet soils, where old stumps and old deadwood were occasionally encountered. We used chainsaws to extract wedges from snags, downed logs, and stumps of different age classes. We sampled in the same way a limited number of living trees, and fire killed older trees to build a continuous tree-ring chronology for the dating of older material. In total, we collected 378 samples (Fig. 2). The reconstruction was confined to the area burned in 2014, because of sampling restrictions in neighboring areas.

Wood samples were dried using a drying cabinet and sanded on a belt sander with up to 600-grit sandpaper. We used a binocular microscope with a $\times 3-40$ magnification to cross-date samples using the visual pointer year method (Stokes and Smiley 1968). A total of 282 samples out of 378 were dated, short ring sequences being the main reason for dating difficulties.

\section{Reconstruction of historical fire cycles}

We defined the fire cycle (FC) as the period required to burn the area equal to the total area studied (Johnson and Van Wagner 1985). To reconstruct the historical FCs, we followed the methodology used by Ryzhkova et al. (2020). The method assumes that a fire dated on a site burned a certain area centered on that site. We further assumed that the sum of these areas (later referred to as units) in a given year represented the minimal amount of area burned in the studied landscape in that year. We considered the unit as a circle with a radius of $300 \mathrm{~m}$ (i.e., $\sim 28.27 \mathrm{ha}$ ). The chosen radius reflected both the site density and considers the common size of the topography features (e.g., local depressions and drier portions of the landscape). The chosen unit size also helped us avoid unit overlapping. Since some of these units included water bodies, we used information on the hydrology of the area (Lantmäteriet 2016) to exclude these non-burnable areas from the calculations. Annual aggregation of the burned units allowed us to construct the chronology of annually burned areas of the sampled area.

Using this chronology, we identified periods with temporally stable fire activity, using regime shift analysis (Rodionov 2004). The algorithm identified a regime shift, when sequential $t$-tests showed a significant difference in the accumulated sums of the normalized deviations from the means of two adjacent periods (Rodionov 2004). For that analysis, we set the $\mathrm{L}$ parameter to 10 years, which decreased the algorithm's ability to detect regime shifts of a lesser length. The algorithm also used the Hubert weight parameter to control the weights assigned to the outliers, which was set to 1 . The significance level of the $t$-tests was set at 0.05 . The minimum number of sites was set to 10, which limited our reconstruction to the 1480-2018 period. We then converted the chronology of the burned areas into the period-specific estimates of the fire cycle 
Fig. 2 The study area. Top-right insert, location of Västmanland County, Sweden (red area). Central insert, the area burned in 2014 (red line) within

Västmanland County with forest land (green). The main map, sampled areas (purple circles) within the area burned in 2014 (encircled by the red line), including water bodies (blue) and elevation gradient

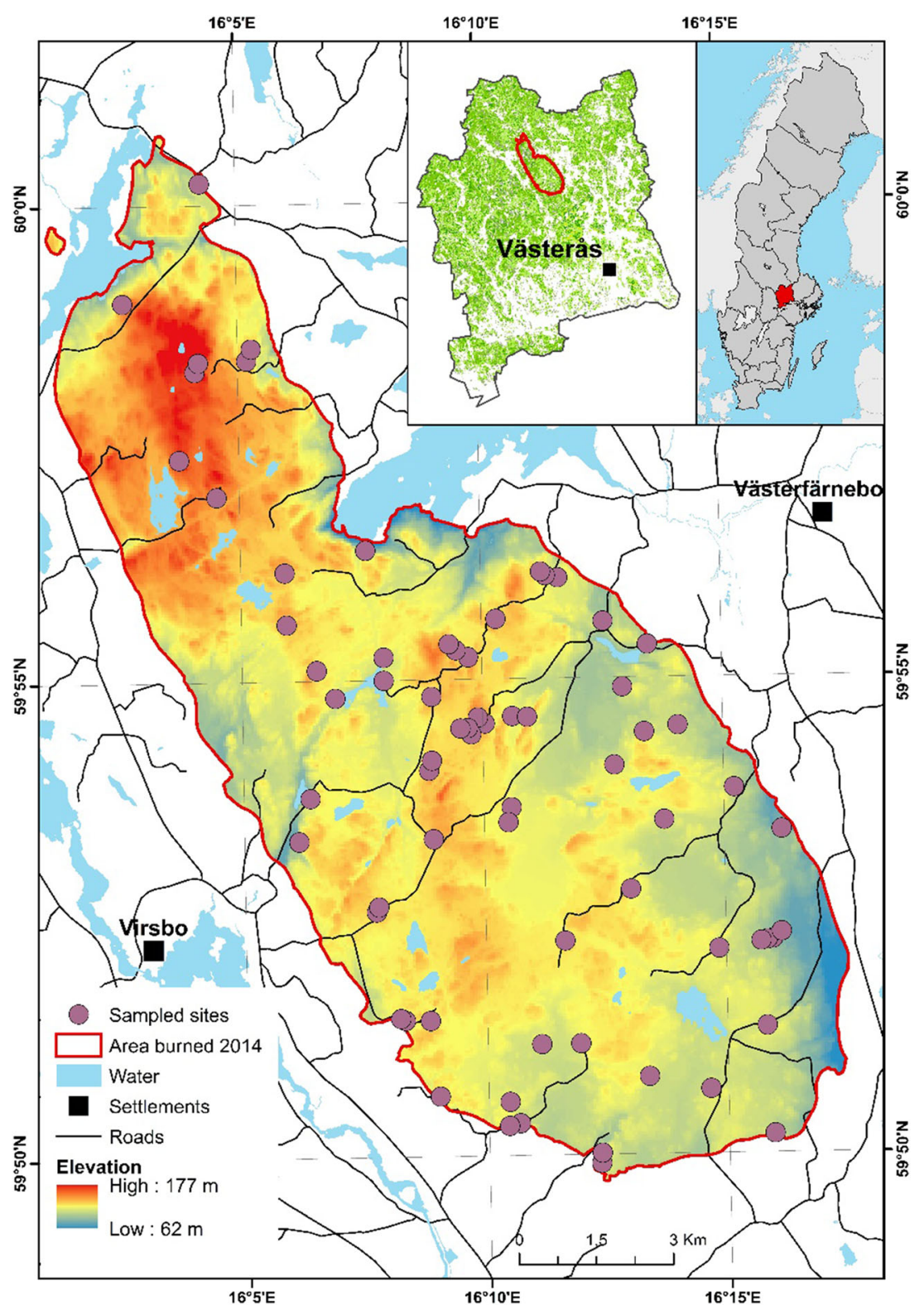

(FC). We bootstrapped the original set of study sites 1000 times to obtain $10 \%$ and $90 \%$ confidence limits for FC for each period identified by the regime shift analysis.

The reduction in the number of samples towards the start of the fire chronology limited its spatial coverage and, therefore, potentially impacted the reconstructed area burned, by reducing the number of burned sites. To address this bias, we adjusted the reconstructed area burned by assuming that the proportion of burned sites in the pool of non-recording sites was the same as the proportion in the pool of recording sites for the year in question. We then randomly classified the sites as burned (alternatively, non-burned) in the pool of nonrecording sites.

\section{Climate-fire analysis}

We used superposed epoch analysis (SEA) (Swetnam 1993; Grissino Mayer and Swetnam 2000) to evaluate the role of climate forcing upon the reconstructed fire years. SEA assessed the statistical significance of departures in the chronology of the drought proxy. We ran SEA separately for three subsets of fire years. The first subset included 5 years with the largest amount of reconstructed area burned for the 1480-1756 (the last fire year before 2014) period. The second subset included 10 largest fire years within 1480-1690, and the third - all fire years during 1690-1756. 
We used the reconstructed standardized precipitation evapotranspiration index (SPEI) for the summer (Seftigen et al. 2017) as the drought proxy. The SPEI reconstruction was built using the total precipitation for the May/June period based on 25 tree-ring series (Seftigen et al. 2017).

\section{Human population data}

We used human population data for the Sala parish, covering the 1571 to 1950 period (Palm 2000; Stads- och kommunhistoriska institutet 2008a) and data for the Sala municipality covering 1951 to 2018 period (Statistics Sweden 2020). Parish data originated from the analysis of tax registers and the number of households, either from the parish itself or from neighboring parishes (Palm 2000) (Nilsson 1992; Nilsson and Lilja 1996). From 1951 to 2018, we used data from the official statistics either from scanned documents (1950-1967) or the online database (1968-2018) (Statistics Sweden 2020). The data for years 1962 and 1965 were not available either in the online database or in the scanned records.

\section{Results}

We dated 302 fire scars from 282 samples (Fig. 3a). The record spanned from 1113 to $2018 \mathrm{AD}$ and contained dates of 64 single fire years from 1130 to 2014 . We identified the seasonality in only 48 fire scars $(\sim 15 \%$ of the total number of dated scars) dated to 30 different fire years. Of these, 43 occurred in the early season (earlywood scars) and five in the late season (latewood scars). The reconstructed area burned exceeded 500 ha in 26 years $(40 \%$ of the total number of fire years), and in ten fire years (15\%), the reconstructed area burned was larger than 1000 ha. A fire-free period of 258 years was identified between 1756 and 2014 .

The regime shift analysis covered the period between 1480 and 2018. Dynamics of both fire occurrence and the area burned showed a change around the turn of the seventeenth and eighteenth centuries (Fig. $3 \mathrm{a}$ and b). In the reconstructed area burned, we observed a change in the FC around 1690 (Fig. 4a, Table 1). The first period between 1480 and 1690 had an FC of 43.57 years, the bootstrapped $90 \%$ confidence envelope being 35 to 57 years. The second period between 1700 and 2018 had an FC of 403 years (with the 90\% confidence envelope of 149 to 7308 years, Table 1).

The regime shift analysis for the fire occurrence also showed a change in regime around 1720 (Fig. 4b, Table 1). The first period between 1480 and 1720 had an occurrence of 1.34 fire years per decade, while the second period (1730 2018) had a mean decadal occurrence of 0.00 (Table 1).

For the SEA analysis, we identified ten large fire years (LFY), i.e., the years with the largest amount of reconstructed area burned: 1523, 1527, 1575, 1585, 1610, 1613, 1631,
Fig. 3 Dendrochronological reconstruction of the fire history between 1130 and 2014. a The summary of site-level data with fire scars (302 fire scars in 64 single fire years, black dots) for each site (69 sites, straight lines). The variation in the periods covered by single sites was due to the variation in the availability of the dated wood covering a particular period. b Reconstructed area burned for the period 1480 2014 with the ten largest fire years (LFY) marked
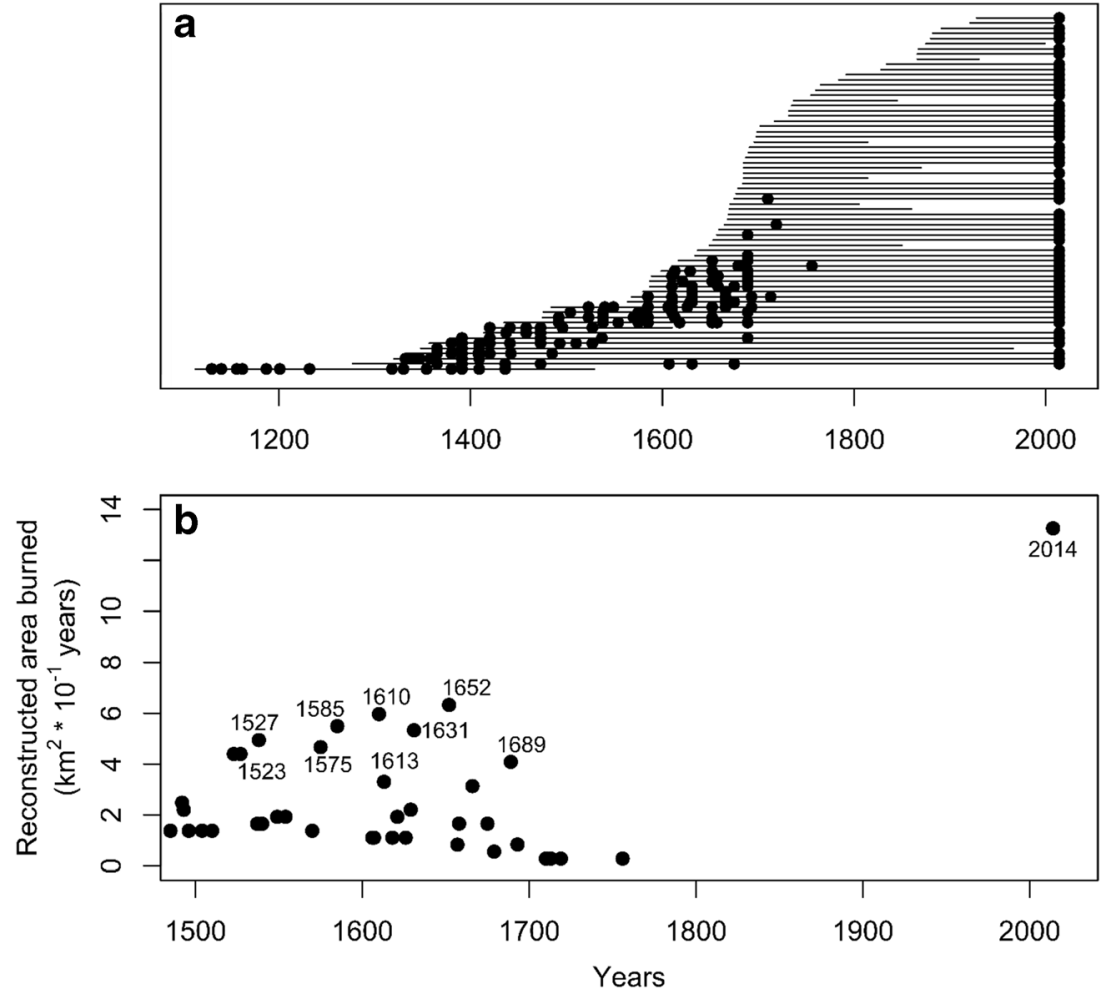
Table 1 Reconstructions of the fire cycle and fire occurrence in the Sala area

\begin{tabular}{llccc}
\hline & Epoch & Mean & $5 \%$ quantile & $95 \%$ quantile \\
\hline Fire cycle (FC) & $1480-1690$ & 43.57 & 35.254 & 57.575 \\
& $1700-2018$ & 403.52 & 149.10 & 7308.65 \\
Decadal fire occurrence & $1480-1720$ & 1.34 & 1.12 & 1.56 \\
& $1730-2018$ & 0.00 & 0.00 & 0.13 \\
\hline
\end{tabular}

1652, 1666, and 1689 (Fig. 3b). We excluded the 2014 event from that list for two reasons. First, the distance in time between this fire and other LFY was large enough to suggest that it occurred under different climate and fuel settings than the reconstructed fires. Second, the conditions under the 2014 fire have been well-documented (MSB 2015). All LFYs occurred in the period with high fire activity, between 1480 and 1690 (Fig. 3b). The reconstructed area burned in all fire years, excluding the 2014 event, had an average of $2.3 \mathrm{~km}^{2}$. The average reconstructed area burned for the 10 LFYs was $4.8 \mathrm{~km}^{2}$. For the $1480-1690$ period it was $2.6 \mathrm{~km}^{2}$ and for $1700-1760$ period $-0.39 \mathrm{~km}^{2}$.

We analyzed the departures of SPEI during three groups of fire years: (1) the five largest fire years during the period with high fire activity $(1575,1585,1610,1631$, and 1652), (2) the ten largest fire years over the period with high fire activity
$(1523,1527,1575,1585,1610,1613,1631,1652,1666$, and 1689), and (3) all the fire years $(n=5)$ in the low activity period (1690-1756), which were identified by the regime shift analysis on the reconstructed area burned. For the later analysis, these fire years were 1693, 1710, 1713, 1719, and 1756 . The SEA showed no significant departures of SPEI in the cases (1) and (2) (Fig. 5a and b). The SEA showed a significant negative SPEI departure for the lag year 0 in the analysis covering the low fire activity period between 1690 and 1756 (Fig. 5c).

\section{Discussion}

The multi-century fire history reconstruction in Sala revealed a period with frequent fires between 1480 (the start
Fig. 4 The reconstructed area burned (a) and the number of sites burned (b), both at decadal resolution, are shown by the black dashed lines. Regime changes in the fire cycle (a) and the fire occurrence (b), as identified by the regime shift analysis, are shown by the red lines. The population data are shown by the blue dashed line. Site replication is shown by the black solid lines

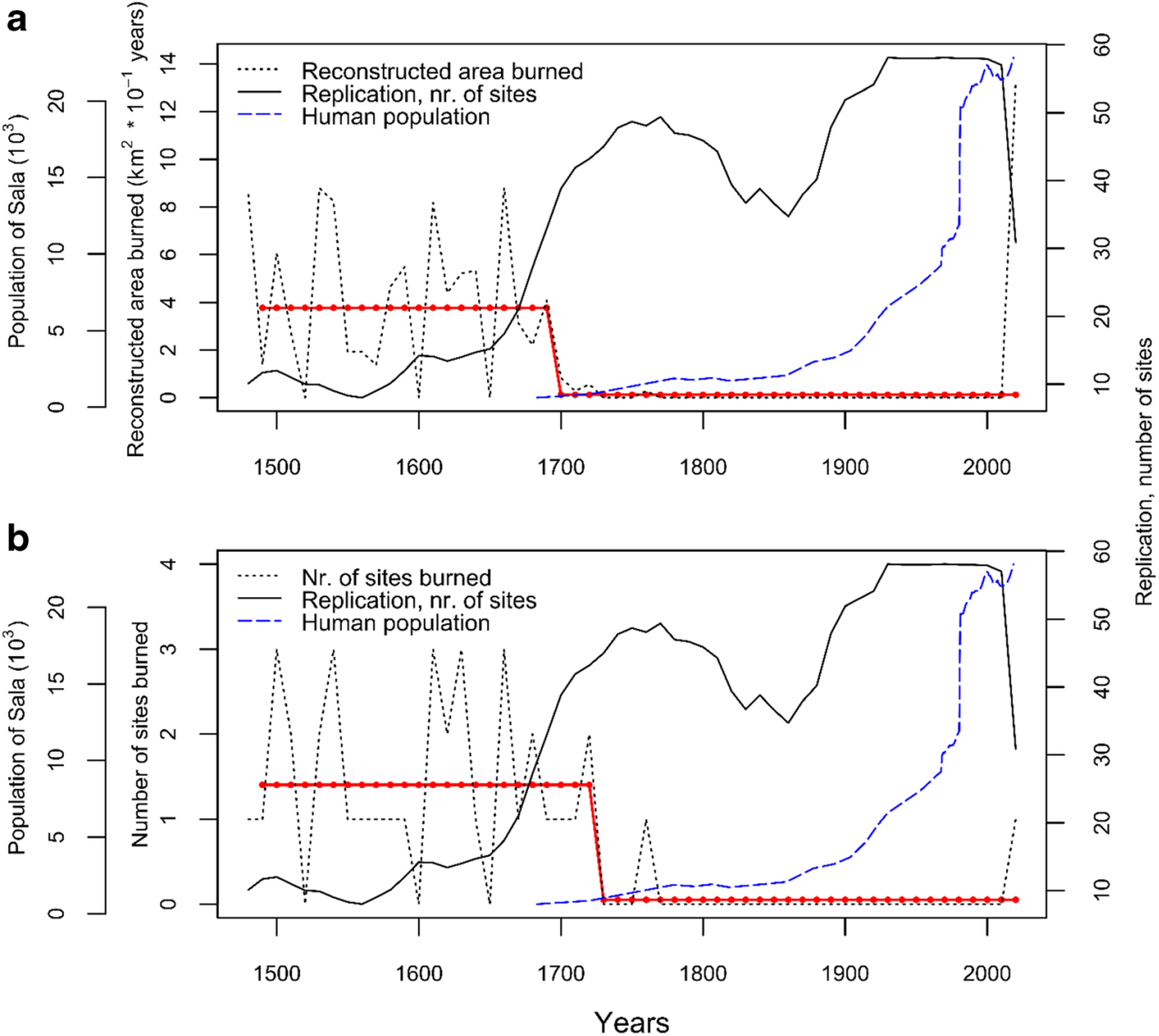


Fig. 5 Superposed epoch analysis of fire years and SPEI reconstruction for the a five largest fire years over the 1480 1690 period, b 10 LFYs over the 1480-1690 period, and $\mathbf{c}$ fire years during the decline period, 1690-1756. Dashed and solid lines refer to the 0.95 and 0.99 confidence intervals, respectively, as estimated by bootstrapping
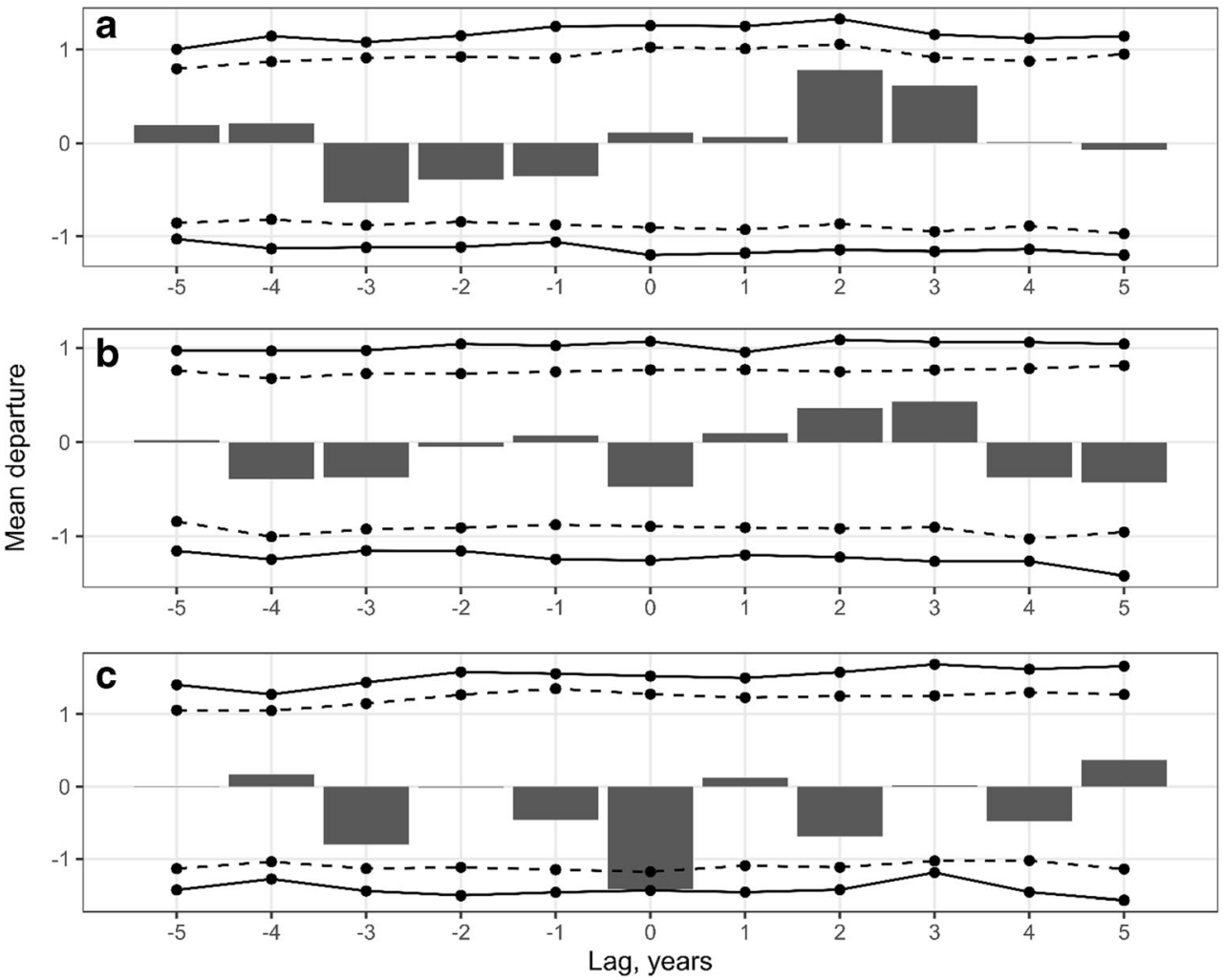

of the reconstruction) and 1690. This was followed by a period with almost non-existent fire activity, with the last pre-2014 fire recorded in 1756. The observed pattern is characteristic of the general decline in forest fires in Fennoscandia during the 1800 s and is well-documented (Niklasson and Granstrom 2000; Pitkänen et al. 2003; Niklasson et al. 2010; Storaunet et al. 2013; Rolstad et al. 2017).

The unique feature of the Sala area appears to be the onset of fire suppression in 1690, the earliest among all currently available reconstructions from Northern Europe (Table 2). Although we did not reconstruct fires of similar size to the one that occurred in 2014, the reconstruction showed that the minimum size of at least four fires dated prior to 1700 were about $40 \%$ of that size (Fig. 3b). However, because our sampling did not extend outside the borders of the area affected by the 2014 fire, it is highly likely that many historical fires reached a similar magnitude as the 2014 fire.

\section{Human impact on fire activity}

The long-term fire history in Sala revealed a century-long decline in fire activity, similar to the reconstructions from other regions in Fennoscandia (Table 2), supporting our hypothesis H1. In Northern Europe, the increase of the economic value of timber and more efficient agricultural production drove the shifts in land use practices responsible for this pattern. In central Sweden, the human presence has impacted the natural fire regime, by slash-andburn agriculture and the mining and production of iron and silver (Emanuelsson and Segerstrom 2002; Segerström and Emanuelsson 2002; Bindler et al. 2011). Both techniques actively used fire to create arable land (slash-and-burn) and to produce charcoal (iron and silver production). The use of slash-and-burn techniques was common in central Sweden from the 1300-1500s until the 1900s (Segerström and Emanuelsson 2002). Iron production has been known in the area between the eleventh century $\mathrm{AD}$ and the middle of the twentieth century (Bindler et al. 2009). The discovery of silver ores at the end of the 1400s and the establishment of furnaces in the 1500s likely had a major impact on the local population and expanded the use of forest burning for the production of charcoal in the region (Östlund 1993; Niklasson and Drakenberg 2001). Throughout the centuries, there were at least 250 ironworks in the Västmanland County alone (Hedenberg 2013).

In Sala, the onset of the period when the land use did not rely on the use of fire (slash burning for food and grazing) occurred much earlier than in other regions of Fennoscandia, where the shift was typically observed in the 1800s (Table 2) (Niklasson and Granstrom 2000; 
Table 2 Dynamics of fire cycles reconstructed in Northern Europe with the help of fire-scar data

\begin{tabular}{|c|c|c|}
\hline The area and the period & $\begin{array}{l}\text { Fire cycle, } \\
\text { years }\end{array}$ & Reference \\
\hline Sala, middle Sweden & & This study \\
\hline $1480-1690$ & 41 & \\
\hline $1700-2014$ & 403 & \\
\hline Tiveden, middle Sweden & & Page et al. 1996 \\
\hline$\sim 1500-1600$ & 75 & \\
\hline$\sim 1600-1700$ & 63 & \\
\hline$\sim 1700-1800$ & 88 & \\
\hline Bjurholm, northern Sweden & & $\begin{array}{l}\text { Niklasson and Granstrom } \\
2000\end{array}$ \\
\hline$\sim 1500-1600$ & 304 & \\
\hline$\sim 1600-1700$ & 217 & \\
\hline$\sim 1700-1800$ & 320 & \\
\hline$\sim 1800-1900$ & 233 & \\
\hline $\begin{array}{l}\text { Hornsö, south-eastern } \\
\text { Sweden }\end{array}$ & & Niklasson et al. 2010 \\
\hline$<1750$ & $64-156$ & \\
\hline $1750-1860$ & $68-175$ & \\
\hline $1900-2003$ & 2556-infinity & \\
\hline \multicolumn{2}{|c|}{ Buskerud, south-central Norway } & Rolstad et al. 2017 \\
\hline $1300-1624$ & 325 & \\
\hline $1625-1799$ & 175 & \\
\hline Lapland, north Finland & & Wallenius et al. 2010 \\
\hline $1400-1800$ & 269 & \\
\hline $1800-2000$ & 546 & \\
\hline Karelia, Russian Karelia & & Ryzhkova et al. 2020 \\
\hline $1400-1630$ & 178 & \\
\hline $1640-1920$ & 46 & \\
\hline 1930-2000 & 283 & \\
\hline
\end{tabular}

Granström and Niklasson 2008; Wallenius et al. 2010; Rolstad et al. 2017). This result supported our hypothesis H2. Two southern Swedish reconstructions show the onset of the fire suppression period in the mid- and late 1700 s, which is still half a century later than in Sala (Niklasson and Drakenberg 2001; Niklasson et al. 2002).

The available record of population density in the Sala area does not provide a conclusive answer on the role of humans in fire dynamics. The first population record of the Sala municipality dates back to 1571 and indicates 624 inhabitants (Palm 2000), approximately corresponding to a population density of 0.5 inhabitants $/ \mathrm{km}^{2}$. The recognition of Sala as a city in 1624 (Stads- och kommunhistoriska institutet 2008b) manifested the economic development of the area and was followed by doubling the local population from 847 in 1620 to 1881 in 1699 (0.7 and 3.9 inhabitants $/ \mathrm{km}^{2}$, respectively). Such an increase inevitably led to a higher demand for food. However, the disappearance of fires during the first half of the $1700 \mathrm{~s}$ suggests that already at the time, the region possessed a sufficient amount of arable land and agricultural practices that would sustain the growing population, ultimately leading to the abandonment of the slash-and-burn.

Paleo-chronological studies have suggested that changes associated with the transition from the cultivation of rye and hay-making to the cultivation of barley may be responsible for a shift from slash-and-burn to possibly fertilized permanent plots or smaller meadow-field rotation (lindbruk or koppelbruk, in Swedish) (Emanuelsson and Segerstrom 2002; Segerström and Emanuelsson 2002). In parallel, an increase in timber value in Scandinavia in the late eighteenth century could play a role in abandoning the use of fire and promote the view of the forested land primarily as a source of timber. We believe that it is primary this economic incentive, rather than adoption of "anti-fire" legislation in Sweden in 1647 , that paved the way for fire-free forest use (Groven and Niklasson 2005; Storaunet et al. 2013).

Similar to other areas in Scandinavia, we expect that fire suppression efforts played a role in decline of fires. However, the inaccessibility to forested areas due to the sparse road network and the lack of mechanized equipment likely limited its effectiveness (Wallenius et al. 2011; Rolstad et al. 2017). There has been no in-depth analysis of the causes of the massive fire decline seen in Scandinavian fire histories to date. Large variability in the onset of fire suppression, as documented in published studies, suggests that multiple factors were involved in the transition from fire-based to fire-free land use. Interpretation of the fire decline trend in a single area, including Sala, therefore, remains speculative.

\section{Climate influence on historical fires}

The two different periods identified by the regime shift analysis varied in the strength of fire-climate relationships. The SEA showed no relationship between the proxy of climatological fire hazard and the occurrence of LFY during the period with high fire activity, 1480-1690, suggesting that humans might be the main driver of fires during this period. The use of the forest for cattle grazing and slash-and-burn for agriculture and charcoal production possibly overrode the influence of climate factors. We also realize that the lack of significance in the SEA may indicate limitations of the climate proxy in capturing sub-seasonal variability in fire hazard (see below).

The significant negative departures of drought proxy in the decline period (1690-1760) indicated that in contrast to the fire-rich era, fires occurred in dry years during that period. This result supported our H3. We speculate that the cessation of active use of fire at the turn of the seventeenth and eighteenth centuries in the Sala area enhanced the climate signal in the fire 
chronology, with fire occurrence being increasingly more controlled by climatic conditions. It is noteworthy that the analysis, which yielded significant departures, was operated on all dated fire years in that period, not a subset of large fire years.

An examination of the SPEI reconstruction revealed the lack of strong drought conditions for the region during the decline period $(\sim 1700-1756)$ (Seftigen et al. 2013), suggesting that both climate and human factors might have contributed to the reduction in fire activity in the first half of the eighteenth century. At the same time, the fire-free period in Sala featured dry and fire prone years. Both the SPEI reconstruction and the synthesis of fire history studies suggested the occurrence of moderate to very dry years and regionally large fire years during the second half of the eighteenth and the nineteenth centuries (Drobyshev et al. 2012; Seftigen et al. 2013). The lack of fires in Sala in that period reinforces the notion that the area might already be under the land use regime disfavoring the fire activity.

The small number of scars dated with seasonal resolution ( $\sim 15 \%$ of all scars) precluded partitioning of the historical fire activity into early and late season events. Seasonal signals were, therefore, difficult to obtain, making the dendroclimatic analyses less powerful. Similarly, the selection of bi-monthly SPEI as a historical drought proxy for the entire fire season assumed a limited within-season variability in drought/fire hazard, which may not necessarily be the case (see discussion in Ryzhkova et al. 2020). Finally, the moderate size of the sampled area $(\sim 14000 \mathrm{ha})$ might prevent our fire reconstruction from capturing the regional climate signal. Indeed, previous studies relying on regional syntheses consistently revealed an association of LFY with regionally dry conditions, resulting from the establishment of high-pressure atmospheric cells over the Scandinavian peninsula (Drobyshev et al. 2012, 2015).

\section{Does fire-free management precondition landscapes for large fires?}

The observation that the largest forest fire in the Swedish history occurred in the area with the longest firesuppression period opens for discussion on the role of humans in affecting both the general flammability of the landscape and the risks for large fire episodes. We speculate that the dynamics of fuel loads and changes in the forest structure, which occurred since the cessation of fire, were of importance in this context. First, fire in boreal forests is an important control of fuel loads (van Wagtendonk 1996; Schimmel and Granström 1997; Agee and Skinner 2005; Mitchell et al. 2009). In the Sala area, fire-associated reduction in fuel loads ceased in the mid-1700s, and it is likely that gradual accumulation of fuels (Schimmel and
Granström 1997), particularly in the organic layer of the soil, occurred during the period dominated by timberoriented forest management. Second, modern forest management exhibits a strong reliance on monodominant coniferous forest stands, resulting in a substantial and general reduction in the proportion of the low-flammable deciduous component (in particular, early successional species, e.g., Betula and Populus) and reduction in the variability of stand age distributions in the landscape. All of these factors contribute to the homogenization of the landscape, in terms of fuel types and their spatial distribution, decreasing the variability in the propensity of forest patches to carry fire. Such homogenization might be another contributing factor facilitating the 2014 fire spread.

Previous fire history reconstructions in Sweden presented records of fires of the same and larger sizes as the fire in 2014 (Niklasson and Granstrom 2000), suggesting that the Swedish landscape and the natural fuel conditions enable large fires to occur. The future scenarios of increasing temperatures and longer fire seasons (Flannigan et al. 2013) and recent increases in the annual area burned (in 2018 fires burned a total of 24000 ha, almost a magnitude larger than the long-term average (Sjöström and Granström 2020) both suggest increasing risks of large fire events. To mitigate these future scenarios, the forest management strategies regarding fire risks in use may need improvements and long-term changes.

These considerations call for a combination of the use of prescribed fires, along with fuel management actions, such as retaining a higher fraction of non-flammable species (Betula, Populus, Alnus) in the landscape, as a means to manage landscape fuel loads and its structural complexity. High structural variation and multi-cohort stands should be the targets of adaptive management (Palik and Zasada 2003; Drobyshev et al. 2008), aiming at both fire risk management and broadly defined restoration of the forest ecosystems used for timber production. In Scandinavia, such prescribed fires are currently carried out exclusively with conservation purposes in mind (Granström 2001; Nilsson 2005). Their use for fuel management in the face of projected increases in extreme drought episodes in Scandinavia (Agee and Skinner 2005) deserves careful consideration.

Acknowledgments The authors would also like to thank Kristina Seftigen for the SPEI data and Oskars Zemītis, Maryjane Heckel, and Wasim Muhammad for the help with the fieldwork.

Funding Open access funding provided by Swedish University of Agricultural Sciences. The study is done within the framework of the NordicFires project, funded by FORMAS (grant \# 2014-01866 to I.D.) Belmont Forum project PREREAL, and the BalticFire network funded by the Swedish Institute (grant \# 24474/2018 to I.D.) and state order to the Karelian Research Centre of the Russian Academy of Sciences (Forest Research Institute KRC). The study is done within the NordicProxy and GDRI Cold Forests networks. 


\section{Compliance with ethical standards}

Conflict of interest The authors declare that they have no conflict of interest.

Open Access This article is licensed under a Creative Commons Attribution 4.0 International License, which permits use, sharing, adaptation, distribution and reproduction in any medium or format, as long as you give appropriate credit to the original author(s) and the source, provide a link to the Creative Commons licence, and indicate if changes were made. The images or other third party material in this article are included in the article's Creative Commons licence, unless indicated otherwise in a credit line to the material. If material is not included in the article's Creative Commons licence and your intended use is not permitted by statutory regulation or exceeds the permitted use, you will need to obtain permission directly from the copyright holder. To view a copy of this licence, visit http://creativecommons.org/licenses/by/4.0/.

\section{References}

Achard F, Eva HD, Mollicone D, Beuchle R (2008) The effect of climate anomalies and human ignition factor on wildfires in Russian boreal forests. Philos Trans R Soc B Biol Sci 363:2329-2337. https://doi. org/10.1098/rstb.2007.2203

Agee JK, Skinner CN (2005) Basic principles of forest fuel reduction treatments. For Ecol Manage 211:83-96. https://doi.org/10.1016/j. foreco.2005.01.034

Ahti T, Hämet-Ahti L, Jalas J (1968) Vegetation zones and their sections in northwestern Europe. Ann Bot Fenn

Amiro BD, Todd JB, Wotton BM, Logan KA, Flannigan MD et al (2001) Direct carbon emissions from Canadian forest fires, 1959-1999. Can J For Res 31:512-525. https://doi.org/10.1139/x00-197

Bindler R, Renberg I, Rydberg J, Andrén T (2009) Widespread waterborne pollution in central Swedish lakes and the Baltic Sea from preindustrial mining and metallurgy. Environ Pollut 157:2132-2141. https://doi.org/10.1016/j.envpol.2009.02.003

Bindler R, Segerström U, Pettersson-Jensen IM, Berg A, Hansson S et al (2011) Early medieval origins of iron mining and settlement in central Sweden: Multiproxy analysis of sediment and peat records from the Norberg mining district. J Archaeol Sci 38:291-300. https://doi. org/10.1016/j.jas.2010.09.004

Conard SG, Ivanova GA (1997) Wildfire in Russian boreal forestspotential impacts of fire regime characteristics on emissions and global carbon balance estimates. Environ Pollut 98:305-313. https://doi.org/10.1016/S0269-7491(97)00140-1

Drobyshev I, Goebel PC, Hix DM, Corace RG, Semko-Duncan ME (2008) Interactions among forest composition, structure, fuel loadings and fire history: A case study of red pine-dominated forests of Seney National Wildlife Refuge, Upper Michigan. For Ecol Manage 256:1723-1733. https://doi.org/10.1016/j.foreco.2008.05.017

Drobyshev I, Niklasson M, Linderholm HW (2012) Forest fire activity in Sweden: climatic controls and geographical patterns in 20th century. Agric For Meteorol 154-155:174-186. https://doi.org/10.1016/j. agrformet.2011.11.002

Drobyshev I, Granström A, Linderholm HW, Hellberg E, Bergeron Y et al (2014) Multi-century reconstruction of fire activity in northern European boreal forest suggests differences in regional fire regimes and their sensitivity to climate. J Ecol 102:738-748. https://oi.org/ $10.1111 / 1365-2745.12235$

Drobyshev I, Bergeron Y, Linderholm HW, Granström A, Niklasson M (2015) A 700-year record of large fire years in northern Scandinavia shows large variability and increased frequency during the $1800 \mathrm{~s} . \mathrm{J}$ Quat Sci 30:211-221. https://doi.org/10.1002/jqs.2765

Drobyshev I, Bergeron Y, De Vernal A et al (2016) Atlantic SSTs control regime shifts in forest fire activity of Northern Scandinavia. Sci Rep 6:22532. https://doi.org/10.1038/srep22532

Emanuelsson M, Segerstrom U (2002) Medieval slash-and-burn cultivation: strategic or adapted land use in the Swedish mining district? Environ Hist Camb 8:173-196. https://doi.org/10.3197/ 096734002129342639

Flannigan M, Cantin AS, de Groot WJ, Wotton M, Newbery A et al (2013) Global wildland fire season severity in the 21st century. For Ecol Manage 294:54-61. https://doi.org/10.1016/j.foreco.2012.10.022

Föreningen Skogen (2019) Skogsbrand - När skogen brinner. In: Skogs Sverige. https://www.skogssverige.se/skog/fakta-om/skogsbrand. Accessed 24 May 2020

Granström A (1993) Spatial and temporal variation in lightning ignitions in Sweden. J Veg Sci 4:737-744. https://doi.org/10.2307/3235609

Granström A (2001) Fire management for biodiversity in the European boreal forest. Scand J For Res 16:62-69. https://doi.org/10.1080/ 028275801300090627

Granström A, Niklasson M (2008) Potentials and limitations for human control over historic fire regimes in the boreal forest. Philos Trans R Soc B Biol Sci 363:2351-2356. https://doi.org/10.1098/rstb.2007.2205

Grissino Mayer HD, Swetnam TW (2000) Century scale climate forcing of fire regimes in the American Southwest. The Holocene 10:213220. https://doi.org/10.1191/095968300668451235

Groven R, Niklasson M (2005) Anthropogenic impact on past and present fire regimes in a boreal forest landscape of southeastern Norway. Can J For Res 35:2719-2726. https://doi.org/10.1139/x05-186

Hedenberg Ö (2013) Järnbruk i Västmanland. Föreningen för smedsläktsforskning, Solna

Hellberg E, Niklasson M, Granström A (2004) Influence of landscape structure on patterns of forest fires in boreal forest landscapes in Sweden. Can J For Res 34:332-338. https://doi.org/10.1139/x03-175

Högbom AG (1934) Om skogseldas förr och nu och deras roll i skogarnas utvecklingshistoria [On forest fires in the past and today and their role in forest succession]. Almqvist \& Wiksell, Uppsala \& Stockholm

Johnson EA (1992) Fire and the population dynamics of boreal trees. In: Press CU (ed) Fire and vegetation dynamics: Studies from the North American Boreal Forest (Cambridge Studies in Ecology). Cambridge University Press, Cambridge, pp 97-107. https://doi. org/10.1017/CBO9780511623516.009

Johnson EA, Van Wagner CE (1985) The theory and use of two fire history models. Can J For Res 15:214-220. https://doi.org/10. 1139/x85-039

Johnstone JF, Chapin FS (2006) Fire interval effects on successional trajectory in boreal forests of Northwest Canada. Ecosystems 9: 268-277. https://doi.org/10.1007/s10021-005-0061-2

Lantmäteriet (2016) GSD-Fastighetskartan Hydrologie (c) Lantmäteriet. https:/www.lantmateriet.se/sv/Kartor-och-geografisk-information/ geodataprodukter/produktlista/hydrografi-nedladdning/. Accessed 9 Aug 2019

Mitchell SR, Harmon ME, O'Connell KEB (2009) Forest fuel reduction alters fire severity and long-term carbon storage in three Pacific Northwest ecosystems. Ecol Appl 19:643-655. https://doi.org/10. 1890/08-0501.1

MSB (2015) Skogsbranden i Västmanland 2014 - Observatörsrapport. Swedish Civil Contingency Agency (MSB), Karlstad

MSB (2017) Incident reports from municipal fire brigades. In: Swedish Civ. Conting. Agency (Myndigheten för samhällsskydd och Beredsk. Swedish). https://www.msb.se/. Accessed 21 Oct 2020

Niklasson M, Drakenberg B (2001) A 600-year tree-ring fire history from Norra Kvills National Park, southern Sweden: implications for conservation strategies in the hemiboreal zone. Biol Conserv 101:6371. https://doi.org/10.1016/S0006-3207(01)00050-7 
Niklasson M, Granstrom A (2000) Numbers and sizes of fires: long-term spatially explicit fire history in a Swedish boreal landscape. Ecology 81:1484. https://doi.org/10.2307/177301

Niklasson M, Lindbladh M, Björkman L (2002) A long-term record of Quercus decline, logging and fires in a southern Swedish Fagus Picea forest. J Veg Sci 13:765-774. https://doi.org/10.1111/j.16541103.2002.tb02106.x

Niklasson M, Drobyshev I, Zielonka T (2010) A 400-year history of fires on lake islands in south-east Sweden. Int J Wildl Fire 19:1050. https://doi.org/10.1071/WF09117

Nilsson L (1992) Historisk tätortsstatistik D. 1 Folkmängden i administrativa tätorter 1800-1970. Stads- och kommunhistoriska institutet, Stockholm

Nilsson M (2005) Naturvårdsbränning - Vägledning för brand och bränning i skyddad skog. Naturvårdsverket, Stockholm, Sweden

Nilsson L, Lilja S (1996) Historisk tätortsstatistik D. 2 Städernas folkmängd och tillväxt : Sverige (med Finland) ca 1570-tal till 1810-tal [in english: Growth and population size of towns in Sweden (with Finland) c. 15701810]. Stads- och kommunhistoriska institutet, Stockholm

Östlund L (1993) Exploitation and structural changes in the north Swedish boreal forest 1800-1992. Swedish University of Agricultural Sciences

Page HD, Niklasson M, Källgren S, Granström A, Goldammer JG (1996) Die Feuergeschichte des Nationalparkes Tiveden (Schweden). Eine kulturhistorische und dendrochronologische Untersuchung. Forstarchiv 68:43-50

Palik B; Zasada J (2003) An ecological context for regenerating multcohort, mixed-species red pine forests. Research Note NC-382. St. Paul, MN: U.S. Dept. of Agriculture, Forest Service, North Central Forest Experiment Station

Palm LA (2000) Folkmängden i Sveriges socknar och kommuner 15711997: med särskild hänsyn till perioden 1571-1751. L. A. Palm, Göteborg

Pinto GASJ, Rousseu F, Niklasson M, Drobyshev I (2020) Effects of human-related and biotic landscape features on the occurrence and size of modern forest fires in Sweden. Agric For Meteorol 291: 108084. https://doi.org/10.1016/j.agrformet.2020.108084

Pitkänen A, Huttunen P, Tolonen K, Jungner H (2003) Long-term fire frequency in the spruce-dominated forests of the Ulvinsalo strict nature reserve, Finland. For Ecol Manage 176:305-319. https:// doi.org/10.1016/S0378-1127(02)00291-8

Rodionov SN (2004) A sequential algorithm for testing climate regime shifts. Geophys Res Lett 31. https://doi.org/10.1029/2004GL019448

Rolstad J, Blanck YL, Storaunet KO (2017) Fire history in a western Fennoscandian boreal forest as influenced by human land use and climate. Ecol Monogr 87:219-245. https://doi.org/10.1002/ecm.1244

Ryzhkova N, Pinto G, Kryshen’ A, Bergeron Y, Ols C et al (2020) Multicentury reconstruction suggests complex interactions of climate and human controls of forest fire activity in a Karelian boreal landscape, North-West Russia. For Ecol Manage 459:117770. https://doi.org/ 10.1016/j.foreco.2019.117770

Schimmel J, Granström A (1997) Fuel succession and fire behavior in the Swedish boreal forest. Can J For Res 27:1207-1216. https://doi.org/ 10.1139/x97-072

Seftigen K, Linderholm HW, Drobyshev I, Niklasson M (2013) Reconstructed drought variability in southeastern Sweden since the 1650s. Int J Climatol 33:2449-2458. https://doi.org/10.1002/joc.3592

Seftigen K, Goosse H, Klein F, Chen D (2017) Hydroclimate variability in Scandinavia over the last millennium - insights from a climate model-proxy data comparison. Clim Past 13:1831-1850. https://doi. org/10.5194/cp-2017-36

Segerström U, Emanuelsson M (2002) Extensive forest grazing and haymaking on mires - vegetation changes in south-central Sweden due to land use since Medieval times. Veg Hist Archaeobot 11:181-190. https://doi.org/10.1007/s003340200021

Sjödin S (2016) The forest fire in Västmanland, South Central Sweden, and its effects on soils and forest recovery (Master's thesis). Uppsala University, Uppsala

Sjöström J, Granström A (2020) Skogsbränder och gräsbränder i Sverige - Trender och mönster under senare decennier (Abstract in English). Karlstad, Sweden

SLU (2017) The Swedish National Forest Inventory - TaxWebb. In: Swedish Univ. Agric. Sci. https://taxwebb.slu.se/pages/ startenglish.aspx. Accessed 11 May 2020

Stads- och kommunhistoriska institutet (2008a) Salas befolkningsutveckling 1650-1995. In: Orthistoria. http:/ortshistoria.se/stad/sala/befolkning. Accessed 9 Apr 2020

Stads- och kommunhistoriska institutet (2008b) Salas historia (in Swedish). In: Orthistoria. http://ortshistoria.se/stad/sala/historia. Accessed 9 Apr 2020

Statistics Sweden (2018) Protected Nature 2017. Stockholm, Sweden https://www.scb.se/en/finding-statistics/statistics-by-subject-area/ environment/land-use/protected-nature/pong/publications/ protected-nature-2017/

Statistics Sweden (2020) Population by region, marital status, age and sex. Year 1968-2019. http://www.statistikdatabasen.scb.se/pxweb/ en/ssd/START_BE_BE0101_BE0101A/BefolkningNy/. Accessed 24 Aug 2020

Stokes MA, Smiley TL (1968) An introduction to tree-ring dating. University of Chicago Press, Chicago

Storaunet KO, Rolstad J, Toeneiet M, Blanck Y (2013) Strong anthropogenic signals in historic forest fire regime: a detailed spatiotemporal case study from south-central Norway. Can J For Res 43:836-845. https://doi.org/10.1139/cjfr-2012-0462

Swetnam TW (1993) Fire history and climate change in Giant Sequoia Groves. Science (80- ) 262:885-889. https://doi.org/10.1126/ science.262.5135.885

van Wagtendonk JW (1996) Use of a deterministic fire growth model to test fuel treatments. Centers for Water and Wildland Resources. University of California, Davis

Wallenius TH, Kauhanen H, Herva H, Pennanen J (2010) Long fire cycle in northern boreal Pinus forests in Finnish Lapland. Can J For Res 40:2027-2035. https://doi.org/10.1139/X10-144

Wallenius TH, Pennanen J, Burton PJ (2011) Long-term decreasing trend in forest fires in northwestern Canada. Ecosphere 2:art53. https:// doi.org/10.1890/ES11-00055.1

Wastenson L, Raab B, Vedin H (1995) National atlas of Sweden [Kartografiskt material] Climate, lakes and rivers. SNA Publ. [Sveriges nationalatlas], Stockholm, Sweden

Wastenson L, Gustafsson L, Ahlén I (1996) National atlas of Sweden [Kartografiskt material] Geography of plants and animals. SNA Publ. [Sveriges nationalatlas], Stockholm, Sweden

Publisher's note Springer Nature remains neutral with regard to jurisdictional claims in published maps and institutional affiliations. 